\title{
Czy w ciągu 15 lat wzrosła akceptacja demokratycznych zasad równości i wolności? - analiza porównawcza postaw studentów
}

\section{KEYWORDS}

attitudes, democracy, the principle of equality and freedom

\begin{abstract}
Czerniawska Mirosława, Czy w ciągu 15 lat wzrosła akceptacja demokratycznych zasad równości i wolności? analiza porównawcza postaw studentów [Has the acceptance of the equality and freedom principles increased over 15 years? A comparative analysis of attitudes among students]. Kultura - Społeczeństwo - Edukacja no. 1(17) 2020, Poznań 2020, pp. 73-93, Adam Mickiewicz University Press. ISSN 2300-0422. DOI 10.14746/ kse.2020.17.4.1
\end{abstract}

The publication deals with the description of attitudes towards the democratic principles of equality and freedom among students. The survey was conducted four times in five-year time intervals $(2003,2008,2013,2018)$. Samples had $325,379,368$, and 371 respondents respectively. The author speculated that the advancement of the transformation is accompanied by growth of the acceptance of prodemocratic attitudes among students, namely the wider acceptance of the principles of equality and freedom. The attitudes were diagnosed using nine pairs of statements (these include both original statements and statements adopted from literature). The hypothesis was not confirmed. The acceptance of the principles of equality and freedom has not increased in consecutive surveys and for many statements the acceptance has decreased.

* ORCID https://orcid.org/0000-0001-7311-5915. 


\section{Wprowadzenie}

Polacy pytani, czy zgadzają się ze stwierdzeniem, że „demokracja ma przewagę nad wszelkimi innymi formami rządów”, odpowiadają prawie 3-7 razy częściej (w zależności od roku badania) twierdząco niż przecząco. Wskaźnik ten wyliczony został na podstawie 31 badań CBOS (2019: 1; w tabeli podany został odsetek osób wybierających jeden z trzech wariantów odpowiedzi: „zgadzam się”, „nie zgadzam się”, „trudno powiedzieć”), które obejmowały lata 1992-2019. Najbardziej pozytywny stosunek do ustroju demokratycznego odnotowano w listopadzie 2007 roku (6,7 razy częściej aprobowano to stwierdzenie niż dezaprobowano), najmniej pozytywny z kolei - w listopadzie 2015 roku (2,7 razy częściej aprobowano to stwierdzenie niż dezaprobowano). Generalnie jednak odsetek osób zgadzających się ze stwierdzeniem, że „demokracja ma przewagę nad wszelkimi innymi formami rządów”, przekraczał zawsze $50 \%$ (zawierał się w przedziale 52-76\%) i był wyższy niż zsumowany odsetek osób odpowiadających: „nie zgadzam się” lub „trudno powiedzieć”.

„Demokracja” jest pojęciem, które wywołuje zazwyczaj pozytywne skojarzenia. Dzieje się tak dlatego, że jest to ustrój sprzyjający w największym stopniu rozwojowi człowieka. Przynależna demokracji ideologia opiera się na dwóch aksjologicznych filarach: „równości” i „wolności”. Z wartości tych wyprowadzane są tak zwane demokratyczne aksjomaty, które przekładają się na zasady regulujące stosunki w sferze politycznej i społecznej. Zgodnie z nimi człowiek - jako obywatel danego kraju - ma równe prawa/szanse niezależnie od identyfikacji narodowościowej, religijnej czy seksualnej (jest to wyraz pozbawionej dyskryminacji polityki państwa). Może również oczekiwać poszanowania autonomii i prawa do dokonywania wyborów. Ujawnia się to w takich sferach, jak wolność słowa, swoboda organizowania się, możliwość przemieszczania (w tym obcokrajowców do Polski) czy prawo do podejmowania decyzji osobistych, także w sferze moralnej. Konsekwencją tak rozumianej wolności może być uniezależnienie od wpływów kultury i religii oraz akceptacja różnorodności.

$\mathrm{W}$ zaprezentowanych w niniejszym artykule badaniach skoncentrowano się na analizie postaw studentów wobec zasad demokracji, które mają swoje źródło w wartości „równość” i „wolność”. Należy zauważyć, że pozytywna ocena demokracji („demokracja ma przewagę nad wszelkimi innymi formami rządów”, por. przytoczone wyżej wyniki badań CBOS, 2019) i przypisywanie dużego znaczenia wskazanym wyżej wartościom, nie oznacza akceptacji wszystkich zasad będących wykładnikiem tego ustroju. Wynika to między innymi z faktu, że pojęcie „demokracja” jest przez ludzi różnie definiowane, niekiedy w sposób drastycznie odbiegający od rozumienia podręcznikowego (na przykład kojarzone jest z państwem opiekuńczym lub dobrobytem materialnym, por. Reykowski, 1995). Ponadto, ak- 
ceptacja pryncypiów demokratycznych wymaga "demokratycznego" typu osobowości, a więc takiego, który cechuje się otwartością, giętkością myślenia i tolerancją odmienności, wysokim poczuciem kontroli wewnętrznej i niekonwencjonalnością, zdolnością do kompromisów, racjonalnością postaw politycznych i aktywną postawą życiową, brakiem wrogości, uznaniem równości ludzi i podmiotowym traktowaniem wszystkich obywateli. Jest to charakterystyka podobna do osobowości samoaktualizującej się w ujęciu Abrahama Maslowa oraz mentalności postmaterialistycznej w ujęciu Ronalda Ingleharta (Czerniawska, 2010). Według ostatniego z wymienionych autorów pryncypia konstytuujące ten typ mentalności zyskują na znaczeniu wraz ze wzrostem dobrobytu społeczeństwa (wyeliminowanie czynników bezpośrednio zagrażających fizycznej bądź ekonomicznej egzystencji), warunkowane są obecnością instytucji demokratycznych i ich powiązaniem z typem kultury politycznej (Frąckowiak-Sochańska, 2009).

\section{Problem badawczy i hipotezy}

W niniejszym badaniu przyjęto rozumienie demokracji jako „synonimu praw i swobód obywatelskich" (Ludwikowski, 1998). Założono, że z dwóch centralnych wartości - „równość” i „wolność” - wynikają określone zasady regulujące stosunki w sferze politycznej i społecznej (por. Czerniawska, 2010). Zdiagnozowano postawy studentów wobec zasad równości praw/szans (równe prawa mniejszości narodowych, religijnych, seksualnych oraz przyzwolenie na pracę zarobkową obcokrajowcom) i wolności (otwarcie na świat, prawo do zrzeszania się w organizacjach społecznych i politycznych niezależnie od państwa, wolność słowa i publicznych wypowiedzi, wolności osobiste, na przykład prawo decydowania w kwestiach aborcji i eutanazji). Starano się ustalić, odnośnie do jakich problemów i jakiej kategorii osób uzasadnione jest ich stosowanie. Badanie przeprowadzono czterokrotnie (cztery grupy studentów o zbliżonej charakterystyce), tj. w latach 2003, 2008, 2013 i 2018, przy użyciu tego samego narzędzia badawczego. Uzyskane w tych pomiarach wskaźniki zostały objęte analizą porównawczą. Założono, że wraz z utrwaleniem instytucji demokratycznego państwa (proces ten ma w Polsce blisko 30-letnią historię) umacniają się postawy prodemokratyczne, tj. wzrasta odsetek studentów akceptujących zasady równości i wolności (hipoteza 1).

Analiza porównawcza postaw diagnozowanych w roku 2003 i 2008 zaprezentowana została we wcześniejszych publikacjach (Czerniawska, 2010; 2011). W niniejszym artykule wykorzystano informacje tam zawarte i fragmenty tekstu (w tym sposób interpretacji zasad równości i wolności), tak, by ukazać zmiany postaw w roku 2013 i 2018. Zastosowano również analogiczną strukturę opisu wyników badań. 


\section{Metoda}

Grupa badana. W badaniu wzięły udział 1443 osoby, z czego 325 (22,52\%) w 2003 roku, $379(26,26 \%)$ - w 2008 roku, $368(25,50 \%)$ - w 2013 roku i 371 $(25,72 \%)$ - w 2018 roku. Cztery grupy były ujednolicone pod względem:

- kierunku kształcenia: około 50\% badanych stanowili studenci pedagogiki Uniwersytetu w Białymstoku i około 50\% badanych - studenci zarządzania Politechniki Białostockiej;

- trybu kształcenia: studia stacjonarne;

- poziomu kształcenia: studenci pierwszego, drugiego i trzeciego roku;

- płci: przewaga liczbowa kobiet (około $80 \%$ );

- wieku: około 90\% badanych stanowili studenci w wieku 20-21 lat.

Uwzględniając przedstawioną powyżej charakterystykę czterech grup badawczych, sądzić można, że cechuje je zbliżony zakres wiedzy na temat rzeczywistości społeczno-politycznej, porównywalny poziom intelektualny, podobne - związane z kierunkiem studiów i okresem rozwojowym - zainteresowania, jak również zbliżone doświadczenia interpersonalne (charakter relacji społecznych). Różnią się one natomiast doświadczeniami związanymi z funkcjonowaniem w nowych warunkach ustrojowych: od roku 1989 - a więc od początku transformacji polityczno-gospodarczej - minęło 14, 19, 24 i 29 lat. Badanie miało charakter anonimowy. Narzędzia badawcze. W niniejszej pracy postawy diagnozowano na podstawie zestawu poglądów wobec zasad demokracji. Respondenci z czterech grup $(2003,2008$, 2013 i 2018 rok) ustosunkowali się do dziewięciu par twierdzeń. Każda para zawiera dwa opozycyjne stanowiska. Zadaniem osób badanych była ocena tych poglądów, tj. wybór jednej z dwóch opcji, tej, która w większym stopniu odzwierciedla przekonania jednostki odnośnie do analizowanych problemów. W ten sposób ustalono, do jakiej kategorii zjawisk oraz osób powinny odnosić się zasady równości i wolności. Postawy 2, 4, 6, 8 i 9 skonstruowane zostały przez autorkę badań. Twierdzenia (bądź ich fragmenty) wchodzące w skład postaw 1, 3, 5 i 7 zaczerpnięto z pracy pod redakcją Janusza Reykowskiego (1993) Wartości i postawy Polaków a zmiany systemowe. Należy podkreślić, że użyte w badaniu własnym twierdzenia są zmodyfikowane (chociaż w różnym stopniu) pod względem treściowym (por. Czerniawska, 2011). Treść twierdzeń zamieszczona jest $\mathrm{w}$ tabeli 1 i na rycinach 1-9.

\section{Wyniki}

W tabeli 1 zamieszczono liczbę osób wybierających jedną z dwóch opcji $(1,2)$ postawy oraz wyniki analizy statystycznej testem $\chi^{2}$. 


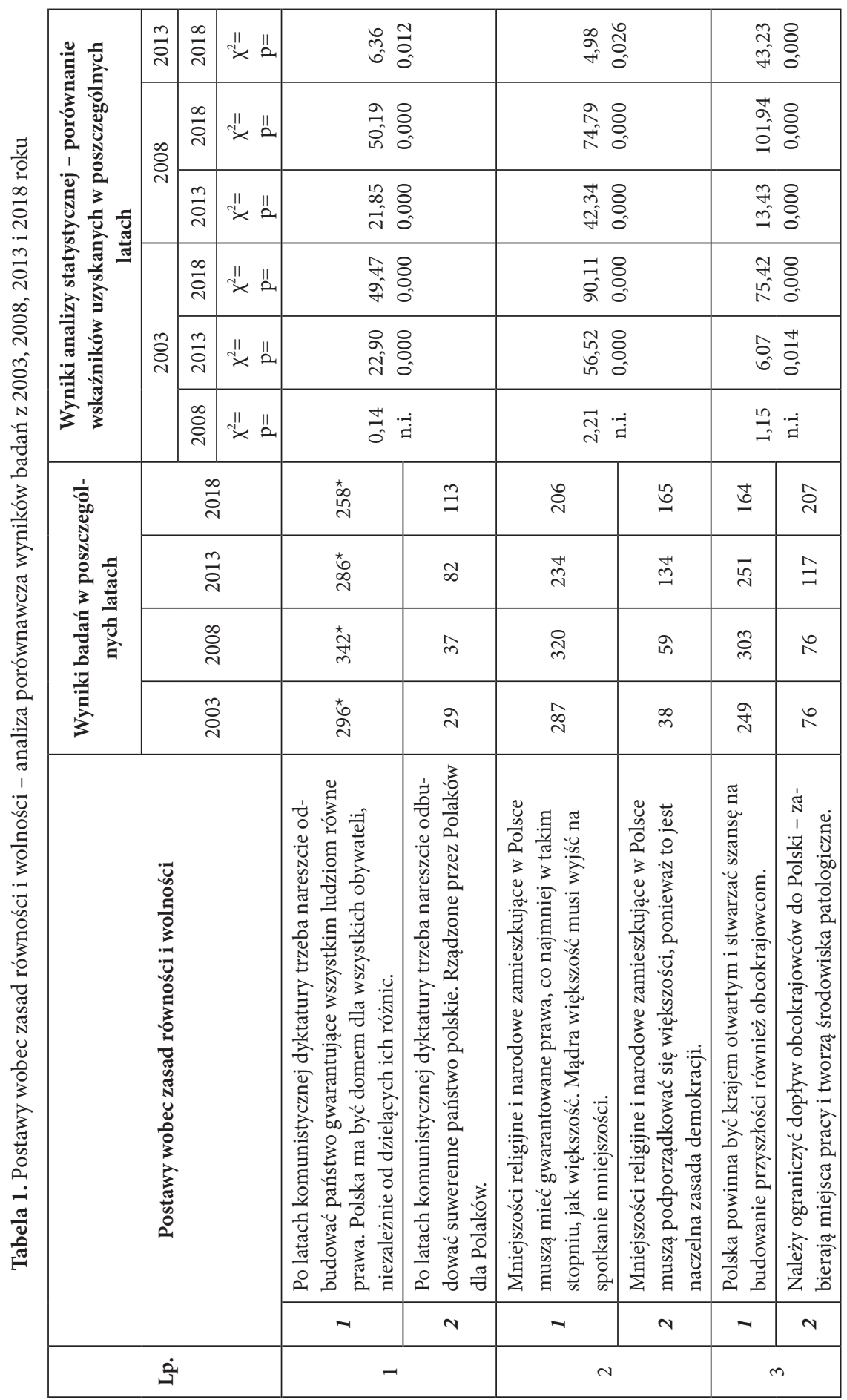




\begin{tabular}{|c|c|c|c|c|c|c|c|c|c|}
\hline \multirow{6}{*}{ 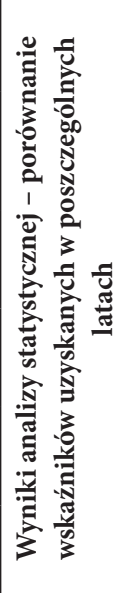 } & $\overrightarrow{\vec{i}}$ & 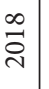 & $\stackrel{\| \prime \prime}{x}$ & \multicolumn{2}{|c|}{$\stackrel{\vec{i}}{i} \cdot \vec{j}$} & \multicolumn{2}{|r|}{$\overrightarrow{0} \cdot \vec{i}$} & \multicolumn{2}{|c|}{$\stackrel{\infty}{\substack{0 \\
0}}$} \\
\hline & $\infty$ & $\begin{array}{l}\infty \\
\stackrel{\infty}{*} \\
\end{array}$ & 光 & \multicolumn{2}{|c|}{$\begin{array}{l}\vec{n} \\
0 \\
0\end{array}$} & \multicolumn{2}{|r|}{$\underset{0}{\Delta} \cdot \vec{H}$} & \multicolumn{2}{|c|}{$\begin{array}{l}\stackrel{2}{2} \cdot \vec{j} \\
\hat{0}\end{array}$} \\
\hline & & $\begin{array}{l}m \\
\vec{n} \\
\vec{n}\end{array}$ & $\stackrel{n}{\| \prime \prime}$ & \multicolumn{2}{|c|}{$\begin{array}{l}: \overrightarrow{0} \\
\stackrel{0}{0} \\
+i \\
0\end{array}$} & \multicolumn{2}{|c|}{$\stackrel{\circ}{\circ} \cdot \vec{a}$} & \multicolumn{2}{|c|}{$\stackrel{\infty}{\Rightarrow} \cdot \vec{\exists}$} \\
\hline & & $\begin{array}{l}\infty \\
\stackrel{\sim}{\sim}\end{array}$ & $\underset{x}{\| \prime \prime}$ & \multicolumn{2}{|c|}{$\begin{array}{l}D_{0}^{0} \\
\text { in } \\
\text { in }\end{array}$} & \multicolumn{2}{|c|}{$\stackrel{\overbrace =}{=}$} & \multicolumn{2}{|c|}{ nू $\hat{\sigma}_{0}$} \\
\hline & 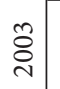 & $\begin{array}{l}m \\
\vec{\sim}\end{array}$ & $\stackrel{\| \prime \prime}{x} \stackrel{\|}{\prime \prime}$ & \multicolumn{2}{|c|}{ 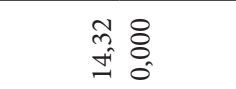 } & \multicolumn{2}{|c|}{ 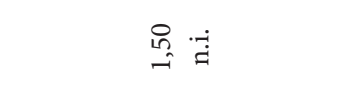 } & \multicolumn{2}{|c|}{ 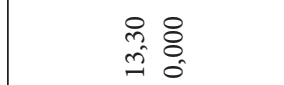 } \\
\hline & & 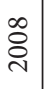 & 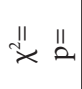 & \multicolumn{2}{|c|}{ 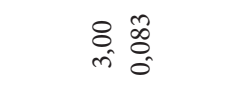 } & \multicolumn{2}{|c|}{$\stackrel{\overbrace{n}}{\sim} \vec{a}$} & \multicolumn{2}{|c|}{ 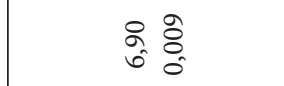 } \\
\hline \multirow{4}{*}{ 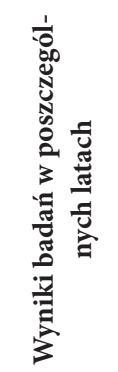 } & \multicolumn{3}{|c|}{$\stackrel{\infty}{\stackrel{\sim}{\sim}}$} & 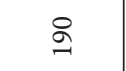 & $\stackrel{\infty}{\sim}$ & 帛 & $\stackrel{i}{i}$ & $\stackrel{\vec{N}}{\sim}$ & $\stackrel{8}{ }$ \\
\hline & \multicolumn{3}{|c|}{$\stackrel{m}{\vec{N}}$} & ఏి & Әे & $\stackrel{m}{m}$ & $\stackrel{\sim}{i}$ & હ & $\bar{a}$ \\
\hline & \multicolumn{3}{|c|}{ 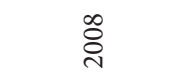 } & त् & $\stackrel{\varrho}{=}$ & $\vec{n}$ & $\stackrel{\infty}{\sim}$ & $\underset{\text { N }}{\mathbb{N}}$ & $\stackrel{\circ}{\ominus}$ \\
\hline & \multicolumn{3}{|c|}{ ڤ̊ } & $\stackrel{2}{\circ}$ & త్ & $\stackrel{\circ}{m}$ & $\stackrel{2}{\sim}$ & $\stackrel{\text { సे }}{2}$ & $\tilde{\Xi}$ \\
\hline & \multirow{2}{*}{\multicolumn{3}{|c|}{ 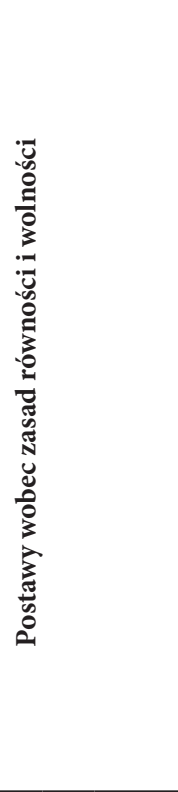 }} & 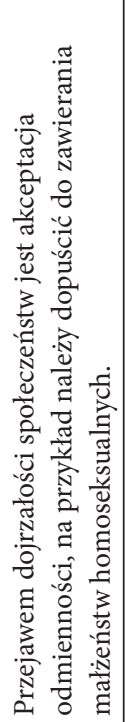 & 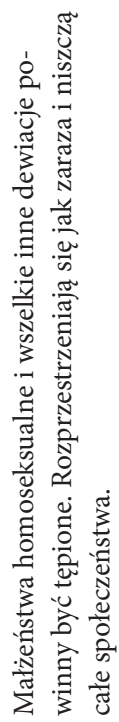 & 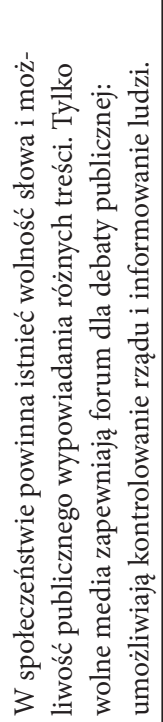 & 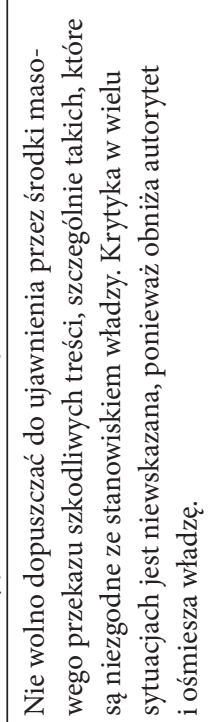 & 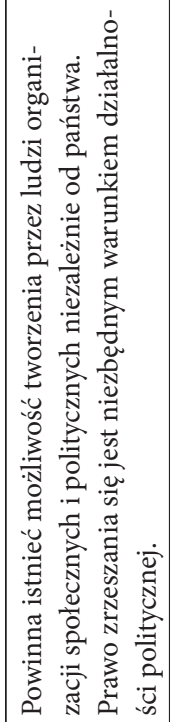 & 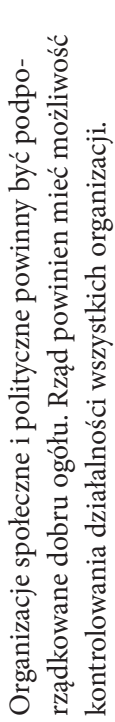 \\
\hline & & & & - & $v$ & - & $v$ & - & $N$ \\
\hline \multicolumn{4}{|c|}{$\stackrel{\dot{\beth}}{2}$} & \multicolumn{2}{|c|}{$r$} & \multicolumn{2}{|r|}{ in } & \multicolumn{2}{|l|}{6} \\
\hline
\end{tabular}




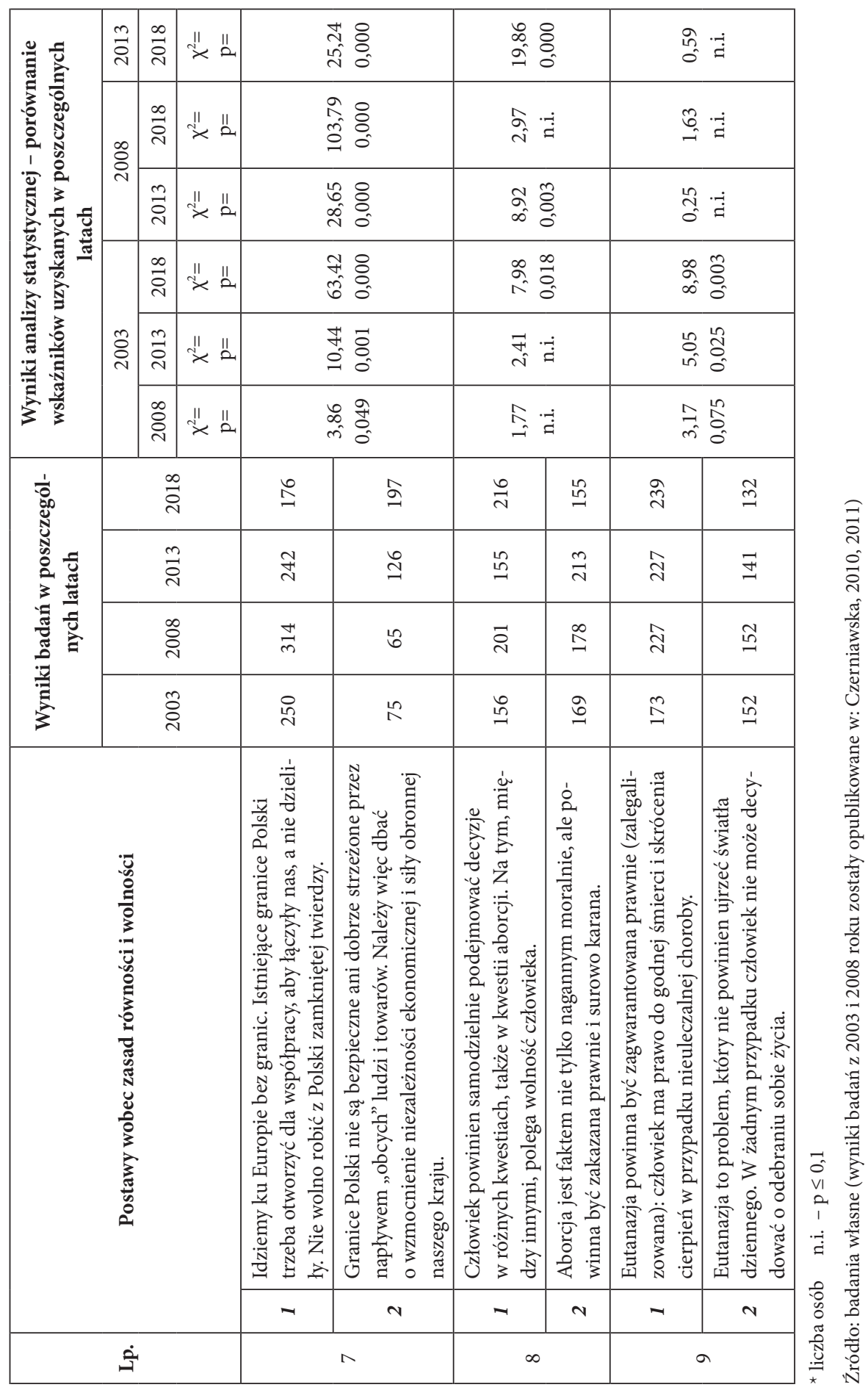




\section{Postawy wobec zasad równości}

Naczelnym hasłem demokracji jest „równość”. Realizacja tej wartości sprzyja zniesieniu dominacji w relacjach międzyludzkich, ustanowieniu pokojowych stosunków i rozwojowi jednostek. Jednym z ważniejszych testów, za pomocą którego można określić stopień demokratyzacji społeczeństwa, jest analiza stosunku do „innych", tj. obcokrajowców, mniejszości narodowych, religijnych i seksualnych. Zgodnie z pryncypiami demokracji osoby należące do mniejszości (poza obcokrajowcami o nieuregulowanym statusie) winny dysponować pełnymi prawami, łącznie z prawem do ochrony własnej tożsamości (Beetham, Boyle, 1994). Jednym z demokratycznych aksjomatów jest to, że władza większości nie może naruszać autonomii mniejszości.

W badaniu starano się zdiagnozować stosunek studentów do hasła „Polska dla Polaków”, a tym samym określić stopień akceptacji idei państwa narodowego.

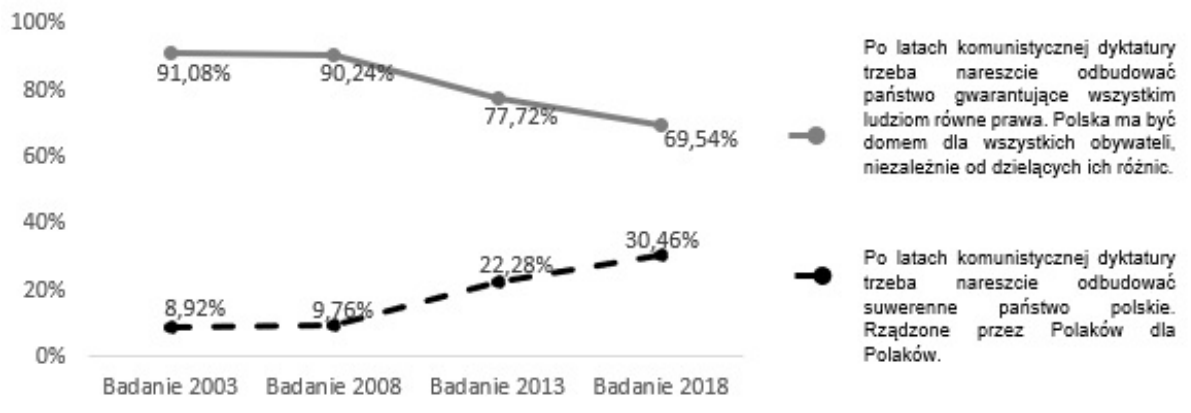

Ryc. 1. Porównanie wyników badań z 2003, 2008, 2013 i 2018 roku: postawa 1

Źródło: badania własne (wyniki badań z 2003 i 2008 roku zostały opublikowane w: Czerniawska, 2010, 2011)

Studenci badani w latach 2003, 2008, 2013 i 2018 byli w większości zwolennikami opcji, że Polska powinna być domem dla wszystkich obywateli, niezależnie od dzielących ich różnic (kolejno: 91,08\%, 90,24\%, 77,72\% i 69,54\%). Niewielka część studentów w 2003 roku (8,92\%) i w 2008 (9,76\%) akceptowała pogląd, że państwo powinno być „rządzone przez Polaków dla Polaków” (por. ryc. 1). Między tymi grupami nie odnotowano różnic istotnych statystycznie (por. tabela 1). Odsetek młodzieży prezentującej takie stanowisko zwiększył się natomiast w dwóch ostatnich badaniach. I tak, w roku 2013 postawę taką prezentowało o 13\% więcej 
studentów niż w roku 2003 i o 12,5\% - niż w roku 2008. W roku 2018 zdiagnozowano taką postawę u 21,5\% więcej studentów niż w roku 2003, u 20,7\% - niż w roku 2008 i 8,2\% - niż w roku 2013. Różnice stwierdzone zostały na wymaganym poziomie istotności statystycznej (por. tabela 1).

Demokracja wiąże się z wolną od dyskryminacji polityką państwa w stosunku do mniejszości religijnych i narodowych.
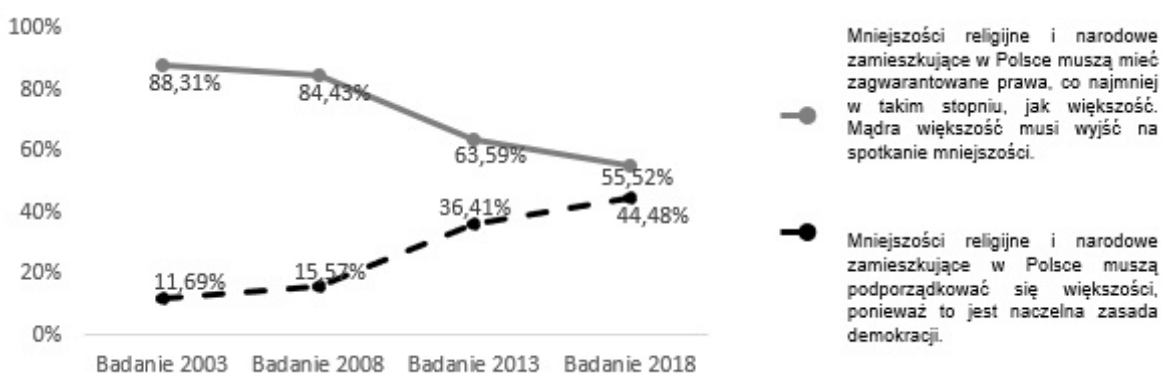

Ryc. 2. Porównanie wyników badań z 2003, 2008, 2013 i 2018 roku: postawa 2

Źródło: badania własne (wyniki badań z 2003 i 2008 roku zostały opublikowane w: Czerniawska, 2010, 2011)

Za zagwarantowaniem równych praw tym grupom opowiadało się kolejno: $88,31 \%$ studentów badanych w 2003 roku, 84,43\% - w 2008 roku, 63,59\% w 2013 roku oraz 55,52\% - w 2018 roku. Jednocześnie, odpowiednio: 11,69\%, 15,57\%, 36,41\% i 44,48\% respondentów było zwolennikami opinii, że mniejszości narodowe i religijne powinny podporządkować się większości (por. ryc. 2). Nie różniły się wskaźniki w pierwszym i drugim badaniu. W trzecim i czwartym badaniu - w porównaniu z dwoma poprzednimi - większy odsetek studentów był przeciwny stosowaniu demokratycznej zasady równości wobec rozpatrywanych grup mniejszościowych. Najwyższe wskaźniki odnotowano w ostatnim badaniu. Porównując grupę diagnozowaną w roku $2013 \mathrm{z}$ dwoma poprzednimi, stwierdzono różnice wynoszące około $24,7 \%$ i 20,8\%, porównując natomiast grupę z 2018 z trzema poprzednimi - różnice 32,8\%, 28,9\% oraz 8,1\% (por. tabela 1).

W następnej kolejności diagnozowano postawy wobec obcokrajowców, przy czym byli oni określeni jako ci, którzy stanowią konkurencję na rynku pracy, zwłaszcza pod względem niższych kosztów wynagradzania. 


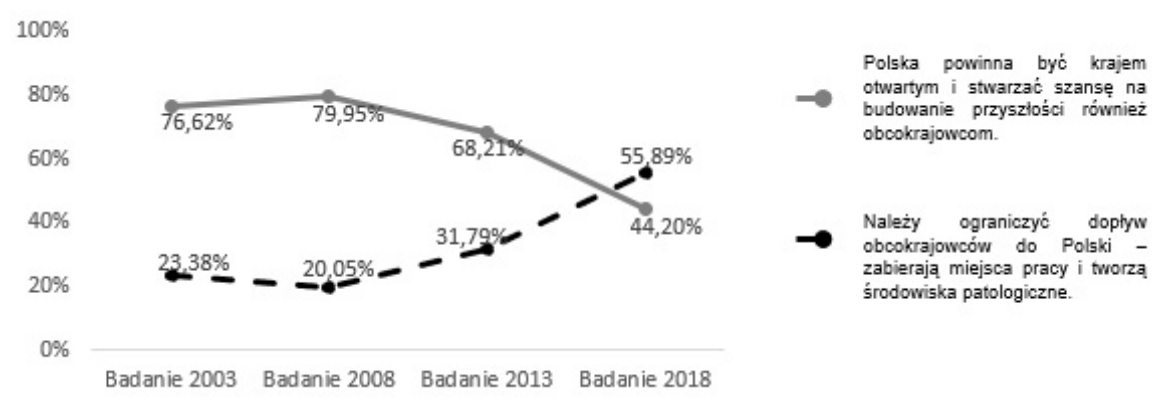

Ryc. 3. Porównanie wyników badań z 2003, 2008, 2013 i 2018 roku: postawa 3

Źródło: badania własne (wyniki badań z 2003 i 2008 roku zostały opublikowane w: Czerniawska, 2010, 2011)

Studenci uczestniczący w trzech pierwszych badaniach opowiadali się w większości (kolejno: 76,62\%, 79,95\% i 68,21\%) za otwartością Polski i stwarzaniem szans obcokrajowcom. W ostatnim badaniu była to już jednak ich mniejsza część (44,20\%). Respondenci z roku 2003 i 2008 w ponad 20\% (23,38\% i 20,05\%) widzieli konieczność ograniczenia dopływu obcokrajowców, upatrując w ich przyjeździe przyczynę bezrobocia i patologii społecznych. W przypadku tych grup nie stwierdzono różnic istotnych statystycznie (por. tabela 1). Odsetek studentów prezentujących taką postawę wynosił w 2013 roku 31,79\%, a więc wzrósł o 8,4\% w stosunku do roku 2003 i o $11,7 \%$ w stosunku do roku 2008. Najwyższy wskaźnik odnotowano jednak w roku 2018, tj. do 51,21\%. Jest on wyższy o $32,4 \%$ w stosunku do roku 2003, o 35,7\% - w stosunku do roku 2008 oraz o 24,0\% - w stosunku do roku 2013 (por. ryc. 3). Opisane wyżej różnice są istotne statystycznie (por. tabela 1).

Stosunek do „innych” rozpatrywany był również w warstwie obyczajowej. Starano się zdiagnozować postawy wobec związków osób homoseksualnych.

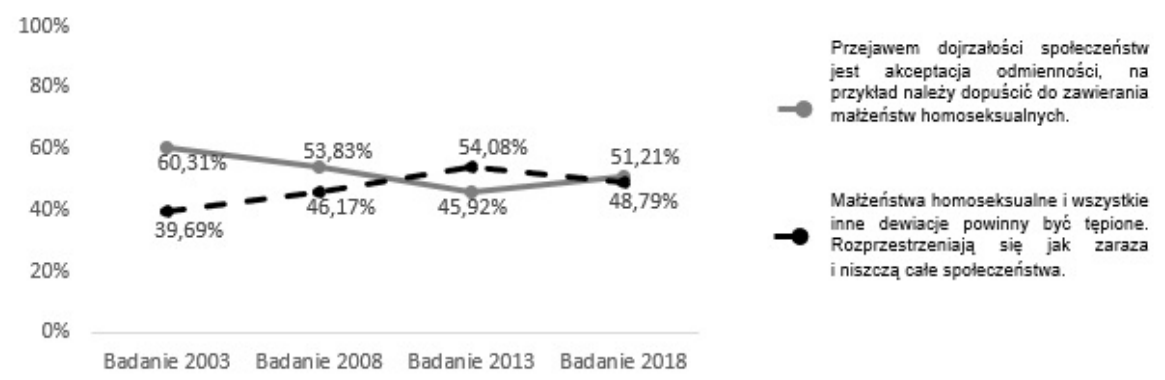

Ryc. 4. Porównanie wyników badań z 2003, 2008, 2013 i 2018 roku: postawa 4

Źródło: badania własne (wyniki badań z 2003 i 2008 roku zostały opublikowane w: Czerniawska, 2010, 2011) 
Pogląd, że należy zalegalizować zawieranie małżeństw homoseksualnych, utrzymywany był przez 60,31\% respondentów w 2003 roku, 53,83\% - w 2008 roku, $45,92 \%$ - w roku 2013 oraz 51,21\% - w roku 2018 (por. ryc. 4). Wskazuje to na stopień akceptacji praw mniejszości seksualnych. Postawy negatywne wobec omawianej kwestii odnotowano relatywnie rzadziej wśród „studentów 2003” (39,69\%) w stosunku do każdej następnej uczestniczącej w badaniu grupy („studenci 2008” 46,17\%, „studenci 2013” - 54,08\%, „studenci 2018” - 48,79\%). Różnice wynosiły kolejno: 6,5\%, 14,4\% i 9,0\% (pierwsza różnica na granicy istotności statystycznej). Relatywnie rzadziej postawy takie deklarowali studenci w 2008 roku niż 2013 roku (różnica 7,9\%) (por. tabela 1).

\section{Postawy wobec zasad wolności}

Demokracja jest identyfikowana $\mathrm{z}$ wolnością, a bardziej konkretnie - z zestawem politycznych, obywatelskich i socjalnych wolności: sumienia, wiary, myśli, poglądów, słowa i szeroko rozumianej aktywności. Stwarza ona możliwość swobodnego debatowania, wyrażania opinii (wolność słowa i prasy), podejmowania własnych inicjatyw, wolnego zrzeszania się obywateli chcących osiągnąć jakieś cele (Krzemiński, 2005). Jednocześnie wolność nie może wychodzić poza ramy prawa, a tym samym prawo określa stopień wolności. Miernikiem ładu demokratycznego (wyznacznikiem demokratycznego państwa) jest zatem konsekwencja w przestrzeganiu wolności i praw obywatelskich.

Wolność słowa rozumiana jest jako prawo wypowiadania się w kwestiach politycznych i wyrażania interesów społecznych. Obejmuje ona krytykę urzędników, rządu, ustroju oraz panującej ideologii. Wiąże się również z dostępem do różnych źródeł informacji oraz ich ochroną prawną (Dahl, 1995; Wasilewski, 2005). Można powiedzieć, że stopień i sposób korzystania z wolności słowa wskazuje na zakorzenienie demokracji w danym społeczeństwie.

Studenci opowiadali się w zdecydowanej większości za wolnością słowa i możliwością publicznego wypowiadania różnych treści („studenci 2003” - 95,38\%, „studenci 2008” - 92,61\%, „studenci 2013” - 93,21\%, „studenci 2018” - 93,00\%). Niewielka część respondentów („studenci 2003” - 4,62\%, „studenci 2008” - 7,39\%, „studenci 2013” - 6,79\%, „studenci 2018” - 7,00\%) wyraziła pogląd, że pewne treści nie powinny być ujawniane, a mianowicie takie, które obniżają autorytet władzy (por. ryc. 5). W wyborze opcji postawy nie stwierdzono różnic istotnych statystycznie (por. tabela 1). W przemianach demokratycznych w Polsce silnie podkreślane były idee związane $\mathrm{z}$ wolnością słowa. Znaczenie wolności w tym zakresie uwidoczniło się w każdej grupie, bez względu na rok, w którym przeprowadzono badanie. 


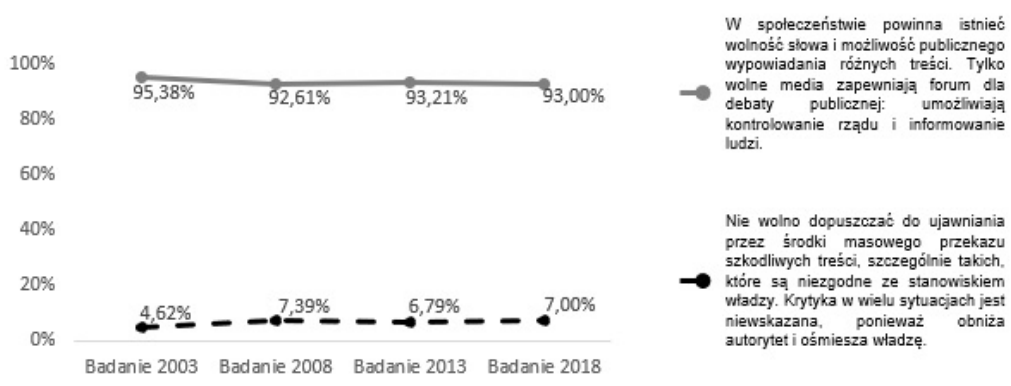

Ryc. 5. Porównanie wyników badań z 2003, 2008, 2013 i 2018 roku: postawa 5

Źródło: badania własne (wyniki badań z 2003 i 2008 roku zostały opublikowane w: Czerniawska, 2010, 2011)

Jednym z istotnych wyznaczników przekształceń ustrojowych jest formowanie się społeczeństwa obywatelskiego, opierającego się na pluralizmie organizacji i dobrowolnym, oddolnym współdziałaniu. Obywatelom powinno przysługiwać prawo tworzenia względnie niezależnych organizacji (w tym partii politycznych), klubów, stowarzyszeń czy fundacji, które umożliwiają wyrażanie i uzgadnianie interesów różnych grup społecznych, kontrolę władzy, wspólne działanie w realizacji określonego celu i podnoszenie jakości życia społecznego. Prawo to ujmowane jest kontrastowo w stosunku do modelu poprzedniego - państwa monocentrycznego - które stanowiło organizację narzuconą odgórnie i opartą na przymusie (Dahl, 1995; Bartkowski, Jasińska-Kania, 2002; Wasilewski, 2005; Radziewicz-Winnicki, 2008).

Próbując zdiagnozować poglądy w omawianej kwestii, poproszono młodzież o ustosunkowanie się do przedstawionych na kolejnym rysunku twierdzeń:

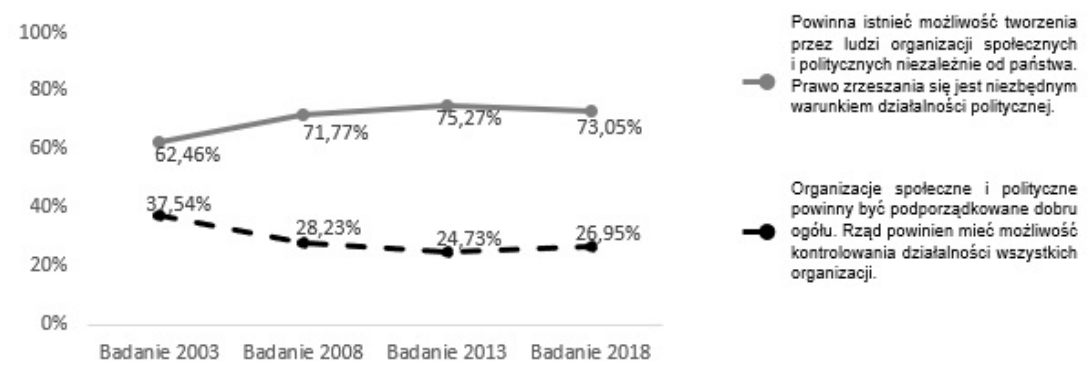

Ryc. 6. Porównanie wyników badań z 2003, 2008, 2013 i 2018 roku: postawa 6 
Większość respondentów („studenci 2003” - 62,46\%, „studenci 2008” 71,77\%, „studenci 2013” - 75,27\%, „studenci 2018” - 73,05\%) uznawała za słuszne prawo obywateli do zrzeszania się, traktując je jako warunek konieczny działalności politycznej. Z kolei 37,54\% osób uczestniczących w pierwszym badaniu, $28,23 \%$ - w drugim, $24,73 \%$ - w trzecim i $26,95 \%$ - w czwartym utrzymywało pogląd, że tego typu organizacje powinny być podporządkowane dobru ogółu, zaś rząd powinien mieć możliwość ich kontroli (por. ryc. 6). Jak można zauważyć, stanowisko to było popularniejsze wśród „studentów 2003” niż wśród „studentów 2008” (różnica 9,3\%), „studentów 2013” (różnica 12,8\%) i „studentów 2018” (różnica 10,6\%). Przy porównaniu wskazanych grup uzyskano wymagany poziom istotności statystycznej (por. tabela 1).

W kontekście prezentowanych badań własnych zaobserwowano różnice międzygrupowe w przypadku wyboru opcji postawy: „otwarcie granic dla współpracy między krajami” versus „strzeżenie granic przed napływem obcych ludzi i towarów” i „Wzmocnienie niezależności ekonomicznej i siły obronnej kraju”.

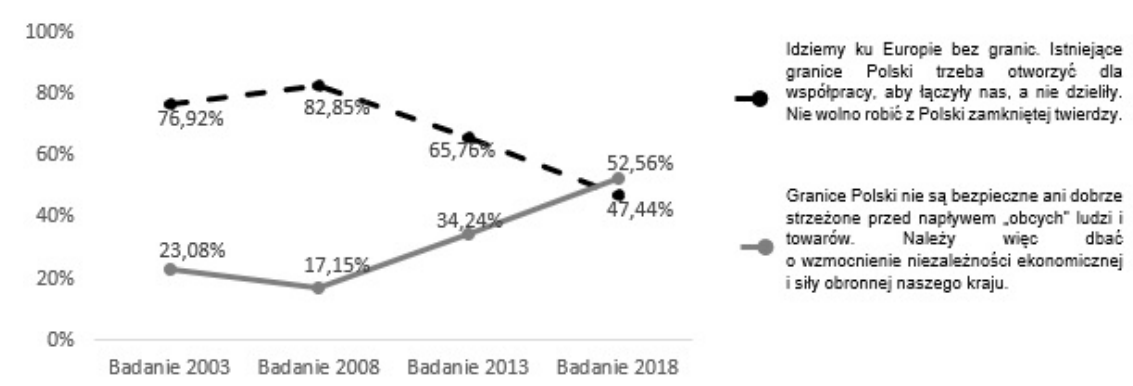

Ryc. 7. Porównanie wyników badań z 2003, 2008, 2013 i 2018 roku: postawa 7

Źródło: badania własne (wyniki badań z 2003 i 2008 roku zostały opublikowane w: Czerniawska, 2010, 2011)

Zwolennikami poglądu, że granice państwa trzeba otworzyć, umożliwiając tym samym współpracę między narodami było: 76,92\% studentów w 2003 roku, 82,85\% w 2008 roku, 65,76\% - w 2013 roku oraz 47,44\% - w 2018 roku. Na konieczność ochrony granic oraz wzmocnienia niezależności ekonomicznej i siły obronnej kraju wskazywało kolejno: 23,08\%, 17,15\%, 34,24\% i 52,56\% studentów (por. ryc. 7). Ujmując porównawczo wskaźniki uzyskane w dwóch pierwszych badaniach, można zaobserwować spadek przekonań izolacjonistycznych (różnica 5,9\%). Należy za- 
uważyć, że drugie z omawianych badań przeprowadzono trzy lata po wstąpieniu Polski do Unii Europejskiej i jego wyniki odzwierciedlać mogą pozytywne następstwa tego faktu. W dwóch ostatnich badaniach odnotowano istotnie większy odsetek tego rodzaju przekonań w stosunku do roku 2003 (kolejno: o 11,2\% oraz 29,5\%), a zwłaszcza - w stosunku do roku 2008 (kolejno: 17,1\% oraz 35,4\%) (por. tabela 1).

Problem wolności osobistych rozpatrywano analizując postawy studentów wobec aborcji i eutanazji.

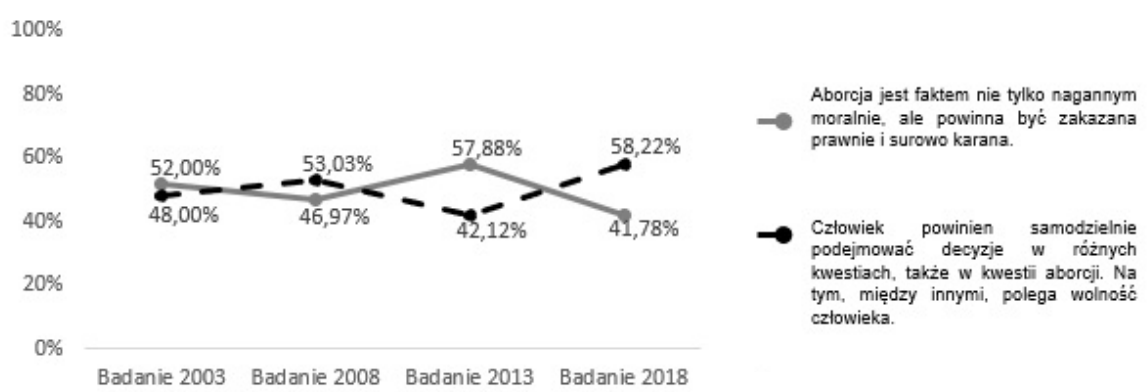

Ryc. 8. Porównanie wyników badań z 2003, 2008, 2013 i 2018 roku: postawa 8

Źródło: badania własne (wyniki badań z 2003 i 2008 roku zostały opublikowane w: Czerniawska, 2010, 2011)

Problem dopuszczalności aborcji jest w Polsce przedmiotem rozlicznych dyskusji. Opinie w tej kwestii polaryzują społeczeństwo, co uwidacznia się także w przedstawionej poniżej analizie. Okazało się, że w następujących po sobie badaniach przeciwnikami aborcji z moralnego i prawnego punktu widzenia było: $52,00 \%, 46,97 \%, 57,88 \%$ i $41,78 \%$ studentów. Z kolei 48,00\%, 53,03\%, 42,12\% i 58,22\% studentów rozważało podjęcie tej decyzji w kategoriach osobistego wyboru i interpretowało ją jako przejaw wolności osobistych (por. ryc. 8). Różnice istotne statystycznie $\mathrm{w}$ wyborze opcji postawy ujawniły się przy porównaniu grup badanych w roku 2008 i 2013. Wzrósł odsetek osób rygorystycznie potępiających aborcję (różnica 10,9\%). Ujawnily się one także przy porównaniu grupy z 2018 roku z grupami z 2003 i 2013 roku. Okazało się, że zmniejszył się odsetek osób prezentujących takie postawy (kolejno: $10,2 \%$ oraz $16,1 \%$ )

Kontrowersyjne stanowiska ujawniły się również wobec problemu eutanazji. Wśród studentów wyodrębniły się dwie podgrupy: przeciwników eutanazji („studenci 2003” - 46,77\%, „studenci 2008” - 40,11\%, „studenci 2013” - 38,32\% i „studenci 2018” - 35,58\%) i jej zwolenników (odpowiednio: 53,23\%, 59,89\%, $61,68 \%$ i $64,42 \%$; por. ryc. 9). W stosunku do roku 2003 wzrósł w trzech kolejnych 


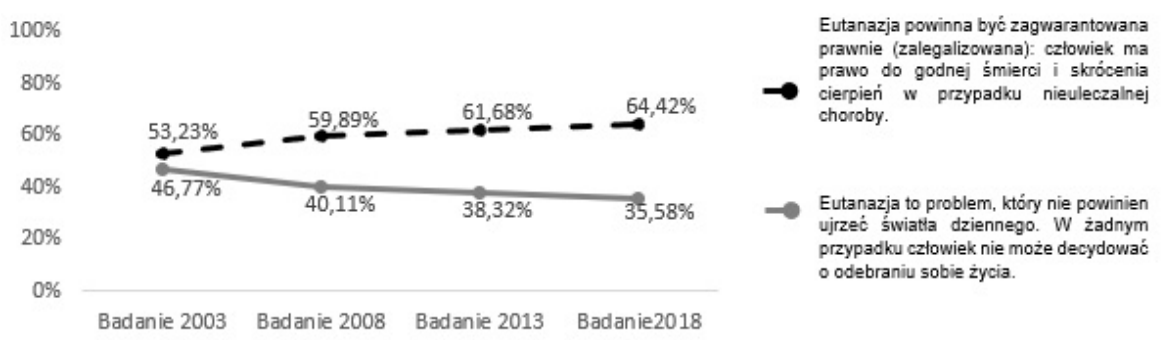

Ryc. 9. Porównanie wyników badań z 2003, 2008, 2013 i 2018 roku: postawa 9

Źródło: badania własne (wyniki badań z 2003 i 2008 roku zostały opublikowane w: Czerniawska, 2010, 2011)

badaniach odsetek osób utrzymujących, że eutanazja powinna być zalegalizowana prawnie, zaś człowiek ma prawo do godnej śmierci w przypadku nieuleczalnej choroby (w roku 2008 - o 6,7\%, w roku 2013 - o 8,4\%, zaś w roku 2018 - o 11,2). Wskazane różnice stwierdzono na wymaganym poziomie istotności statystycznej (por. tabela 1).

\section{Wnioski i podsumowanie}

Demokracja sprzyja budowie nowoczesnego państwa. Rozwój instytucji demokratycznych w Polsce miał przyczynić się do uzgodnienia na zasadzie równości stosunków społecznych oraz uzyskania wolności politycznej i osobistej. Naturalny wydaje się fakt, że przesłanki ideologiczne będą coraz silniej zakorzeniać się w mentalności obywateli i przyczyniać do kreacji systemu.

Celem niniejszych badań było ustalenie, jaki zakres stosowania zasad równości i wolności jest - zdaniem respondentów - uzasadniony i kto powinien lub nie powinien być ich adresatem. Z pierwszej zasady wynika równe prawo do aktywności w różnych obszarach (bez względu na między innymi przynależność narodową, religijną czy orientację seksualną), z drugiej - autonomia, swoboda działania i jak największa prywatność, która nie jest ograniczana ingerencją państwa (Żardecka-Nowak, 2001). Analizę wyników przeprowadzono w dwóch wymiarach: określono dominujące postawy oraz scharakteryzowano różnice między nimi, uwzględniając kryterium czasowe, tj. rok przeprowadzenia badań (2003, 2008, 2013 i 2018). Oczekiwano, że w każdym następnym badaniu coraz większy odsetek studentów deklarować będzie postawy prodemokratyczne. Taka hipoteza wydawała się zgodna z „logiką” przeobrażeń systemowych. 
Uzyskane wyniki wskazują przeważnie na wysoką lub przynajmniej umiarkowaną (ponad 50\% uczestników każdego badania) akceptację demokratycznych zasad równości. Respondenci przynależni do czterech grup opowiadali się w większości za równością praw wszystkich obywateli (postawa 1) oraz mniejszości narodowych i religijnych (postawa 2) (wskaźniki procentowe około 55-90\%). Trzy pierwsze grupy opowiadały się za stworzeniem szans osobom, które nie są obywatelami kraju, tj. obcokrajowcom podejmującym pracę zarobkową (postawa 3) (wskaźniki procentowe około 68-80\%). Niemniej jednak, w grupie diagnozowanej w roku 2018 postawa ta stała się mniej popularna i cechowała $44 \%$ respondentów. Za przyznaniem równych praw mniejszości homoseksualnej opowiadało się ponad 50\% respondentów w trzech badaniach i tylko w roku 2013 wskaźnik ten wynosił $46 \%$.

W niniejszym badaniu przyjęto „optymistyczną” hipotezę, że akceptacja zasady równości będzie rosła „z badania na badanie”. Uzyskane wyniki nie potwierdzają jednak tego założenia i analiza porównawcza wskazuje na bardziej złożone prawidłowości. W przypadku trzech pierwszych postaw zaobserwowano interesującą prawidłowość: ich wskaźniki były zbliżone, gdy ujmowano porównawczo dane zebrane w dwóch pierwszych badaniach (rok 2003 i 2008), były istotnie niższe w badaniu trzecim (rok 2013) i jeszcze niższe - w czwartym (rok 2018). W najbardziej lakoniczny sposób można sformułować wniosek: od 2013 roku stosunkowo więcej studentów opowiadało się za „zmniejszeniem” równości obywateli niebędących etnicznymi Polakami i katolikami oraz za ograniczeniem dopływu obcokrajowców. Jest to wynik niezgodny z hipotezą. Hipoteza nie została również potwierdzona, gdy analizą objęto postawę wobec praw mniejszości homoseksualnej (postawa 4). Okazało się, że w pierwszym badaniu odsetek studentów opowiadających się za takimi prawami był wyższy niż w każdym następnym. Odsetek ten był także wyższy w badaniu drugim niż w trzecim.

Większość respondentów w czterech grupach badawczych akceptowała demokratyczną zasadę wolności i takie jej przejawy, jak: wolność słowa i wyrażanie opinii, nawet wtedy, gdy są sprzeczne z poglądami władzy, prawo do podejmowania własnych inicjatyw i stowarzyszania się w organizacjach, które nie są objęte kontrolą państwa (postawa 5 i 6; wskaźniki procentowe około 60-95\%). Respondenci trzech pierwszych grup wskazali w większości na konieczność budowy otwartego społeczeństwa (postawa 7; wskaźniki procentowe około 65-83\%). W grupie czwartej postawę taką deklarowało natomiast poniżej 50\% respondentów. Jednocześnie należy zauważyć, że swobody obywatelskie w wymiarze politycznym (omówiona wyżej postawa 5, 6 i 7) wartościowane były wyżej niż swobody w wymiarze osobistym (postawa 8 i 9). Uwidoczniło się to zwłaszcza w postawie wobec aborcji (postawa 8; wskaźniki procentowe około 40-58\%). 
W opisywanym badaniu założono, że wraz z utrwaleniem instytucji demokratycznego państwa, umacniają się postawy prodemokratyczne, co przejawia się we wzroście odsetka studentów akceptujących zasadę wolności. Czy pojawiły się istotne statystycznie różnice $\mathrm{w}$ deklarowanych postawach w czterech badaniach? Nie odnotowano ich po dokonaniu analizy porównawczej postaw wobec wolności słowa (postawa 5). Oczekiwany w hipotezie "progres” ujawnił się w postawie odnoszącej się do prawa zrzeszania w organizacje niezależne od państwa (postawa 6). Niemniej jednak prawo to było akceptowane przez większy odsetek respondentów trzech ostatnich grup tylko wtedy, gdy porównywano je z pierwszą. Zestawienie opcji postawy 7: „Idziemy ku Europie bez granic...” i „... należy dbać o wzmocnienie niezależności ekonomicznej i obronnej kraju" ujawniło interesujące zależności. Akceptacja „otwartości” wzrosła w roku 2008 w porównaniu z rokiem 2003, ale obniżyła się w roku 2013 w stosunku do dwóch poprzednich badań. Najniższe wskaźniki względem trzech poprzednich grup pojawiły się w roku 2018. Wyniki analizy porównawczej nie pozwalają na potwierdzenie przedstawionej wyżej hipotezy: postawy albo się nie zmieniają (postawa 5), albo zmiany odnotowuje się tylko w stosunku do 2003 roku (postawa 6), albo przebiegają one w kierunku przeciwnym do założonego w dwóch ostatnich badaniach (postawa 7). Porównując dane zgromadzone w czterech pomiarach, należy zauważyć, że prawo do podejmowania samodzielnych decyzji w kwestii aborcji było akceptowane przez większy odsetek studentów $\mathrm{w}$ ostatnim badaniu $\mathrm{w}$ porównaniu $\mathrm{z}$ badaniami przeprowadzonymi w roku 2003 i 2013. Nie odnotowano jednak zmian w akceptacji takiego poglądu „Z badania na badanie”. Co więcej, w roku 2013 w porównaniu z rokiem 2008 zmalał (a nie wzrósł) odsetek studentów utrzymujących, że decyzja o aborcji powinna być podejmowana samodzielnie. Prawo do eutanazji (postawa 9) było - co prawda - akceptowane w późniejszych badaniach przez większy odsetek studentów, ale wniosek ten odnosi się do określonych porównań, tj. pierwszej grupy z trzema pozostałymi. Uniemożliwia to przyjęcie założeń zwerbalizowanych w hipotezie. Uzyskane wyniki badań wskazują, że akceptacja demokracji jako ustroju politycznego nie musi „przekładać się” na akceptację jej wszystkich zasad i wobec wszystkich ludzi. Wskazują także, że nie ma prostego związku między zaawansowaniem procesu demokratyzacji (14, 19, 24 i 29 lat) a akceptacją pryncypiów tego ustroju.

Jakie zdarzenia poprzedzające kolejne badania mogły wpłynąć na stosunek do zasad równości i wolności? Warto na to zwrócić uwagę, ponieważ nieobojętne dla naszych przekonań są doświadczenia związane z życiem w realnie funkcjonującym systemie (Konieczna, 2002). W latach 2000-2003 Polska przeżywała recesję i w większości warstw społecznych narastało poczucie zagrożenia związane z egzystencją ekonomiczną. Drugie badanie odbyło się po jednym z najważniejszych 
wydarzeń w najnowszej historii, które rozbudzało zarówno nadzieje, jak i obawy. W roku 2004 Polska stała się członkiem Unii Europejskiej, zaś w roku 2007 przystąpiła do układu z Schengen, znoszącego kontrolę na wewnętrznych granicach państw-sygnatariuszy dokumentu. W latach 2004-2007 nastąpiło ożywienie gospodarcze i spadły wskaźniki bezrobocia. Konsekwencją psychologiczną tego stanu rzeczy był podwyższający się optymizm Polaków (Gumuła, 2008). Sądzić można, że wzrost pozytywnych nastrojów społecznych przełożył się na pozytywne wartościowanie ustroju i umocnienie zaufania do zasad leżących u jego podstaw. Taki stan rzeczy uwidocznił się w wynikach badań własnych przeprowadzonych w roku 2008, w których studenci prezentowali postawy prodemokratyczne w relatywnie większym stopniu. Odwołując się do cytowanych wyżej badań CBOS (2019), należy także wskazać, że najprzychylniejszy stosunek do ustroju demokratycznego odnotowano w listopadzie 2007 roku (6,7 razy częściej aprobowano stwierdzenie „demokracja ma przewagę nad wszelkimi innymi formami rządów” niż dezaprobowano). Zdecydowanie trudniejsze były sytuacje poprzedzające trzecie i czwarte badanie. W 2009 roku stały się dostępne ogółowi społeczeństwa informacje na temat światowego kryzysu ekonomicznego. Przez kilka najbliższych lat (a więc w okresie poprzedzającym trzecie badanie) kryzys ten wzmógł nie tylko krytyczne ustosunkowanie do zasad neoliberalnych w gospodarce, ale przełożył się również na interpretację pryncypiów ustroju politycznego. Zła kondycja ekonomiczna społeczeństwa ogranicza „życzliwą” analizę problemu równości obywateli. Zwłaszcza wtedy istotne stają się „dzielące różnice”. Odwołując się po raz kolejny do badań CBOS (2019), należy zauważyć, że najmniej pozytywny stosunek do demokracji stwierdzono w lipcu 2013 roku (tylko 2,9 razy częściej aprobowano stwierdzenie, że „demokracja ma przewagę nad wszelkimi innymi formami rządów” niż dezaprobowano; jeszcze niższy wskaźnik uzyskano tylko w roku 2015). Za wyraz aktywności obywatelskiej w tym okresie należy uznać protesty części społeczeństwa przeciwko podpisaniu przez Polskę umowy ACTA (2012 rok), która mogła naruszać prawo do informacji i wolność słowa.

Lata poprzedzające ostatnie z czterech badań przyniosły nowe doświadczenia. W roku 2014 wybuchła afera podsłuchowa, która ograniczyła zaufanie do ówczesnego rządu. Rok później (już po wyborach parlamentarnych i ukonstytuowaniu się nowego rządu) dokonano zmian w strukturze Trybunału Konstytucyjnego i przeprowadzono reformę sądownictwa. Społeczeństwo zostało podzielone na członków/zwolenników ruchu społecznego KOD i marszów w obronie demokracji oraz ich przeciwników. W zróżnicowany sposób ustosunkowywali się ludzie do tak zwanych czarnych protestów przeciwko całkowitemu zakazowi aborcji (2016 rok). Pojawił się też problem relokacji uchodźców w krajach Unii Europejskiej, w tym 
w Polsce. Inaczej zaczęto spostrzegać „obcych” przybywających z odmiennych kultur. To pięciolecie cechowało się wzrostem zainteresowania sprawami politycznymi i społecznymi. Obfitowało też $\mathrm{w}$ obywatelskie projekty i publiczne demonstracje, w trakcie których konfrontowały się poglądy społeczeństwa - te bardziej i mniej demokratyczne. Zaktywizowało się pytanie: czym jest demokracja, jakie są jej przejawy i czy dana jest ona „raz na zawsze”?

Należy podkreślić, że wyniki badań własnych - jeżeli ujmie się je porównawczo - wywołują pewien niepokój. Wiąże się on z relatywnie niższą akceptacją zasady równości w dwóch ostatnich badaniach w stosunku do dwóch pierwszych. Stosunkowo bardziej atrakcyjne stało się przekonanie, że państwo polskie powinno być rządzone przez Polaków dla Polaków, zaś mniejszości narodowe i religijne powinny podporządkować się większości. Czy jest zatem trafnie różnicowany patriotyzm od nacjonalizmu? Do jakiego stopnia ujawniać powinno się zróżnicowanie między własną grupą i grupą obcą, czy wręcz dewaluacja innych? Stosunkowo częściej optują też studenci za ograniczeniem dopływu obcokrajowców do Polski. Może być to spowodowane nie tylko migracją zarobkową zza wschodniej granicy, ale też pokłosiem dyskusji społecznych nad relokacją uchodźców. Wydaje się to jednak „dziwne”, gdy uwzględni się fakt licznych, motywowanych ekonomicznie, wyjazdów Polaków na Zachód. Kontrowersyjny i mocno dzielący polskie społeczeństwo jest problem równości praw mniejszości homoseksualnej. Uwidacznia się to w organizowanych marszach zwolenników i przeciwników tej równości.

Wstąpienie Polski do Unii Europejskiej i przystąpienie do układu z Schengen umożliwiło współpracę i korzystanie z wolności w „Europie bez granic”. Okazało się jednak, że w dwóch ostatnich badaniach relatywnie bardziej pożądane były posunięcia mające na celu wzmocnienie niezależności ekonomicznej i siły obronnej naszego kraju. Czy zatem - w percepcji studentów - nie zostały zrealizowane oczekiwania związane z członkostwem w Unii? Badani respondenci opowiadali się w większości „za” wolnością polityczną (słowa i zrzeszania się). Nie tak oczywisty był już stosunek do wolności w sferze decyzji osobistych - eutanazji, a zwłaszcza aborcji. Te dwie postawy mają jednak szczególny status. Jak wykazano w badaniach CBOS (2016), zależą one w dużym stopniu od stosunku do religii, nauczania Kościoła i zaangażowania w praktyki religijne. Uzależnione są także od systemu wartości (Czerniawska, 2013).

Analiza wydarzeń - wyborów politycznych, protestów, demonstracji, ustaw sejmowych - skłania do zadania pytania: jak „będą się miały” zasady równości i wolności w świadomości następnego pokolenia studentów? Odpowiedź na to pytanie umożliwią badania planowane na rok 2023. Trzeba jednak mieć na uwadze fakt, że - jak zauważa Zygmunt Bauman (KT, 2014) - ludzie na całym świecie 
przestają wierzyć w system demokratyczny, ponieważ nie dotrzymuje on obietnic. Coraz częściej zwraca się uwagę na problem nierówności, który wynika z kryzysu państwa opiekuńczego, instytucji społecznych i pracy. Coraz częściej pojawia się pytanie jeżeli równość, to równość czego? (Fitoussi, Rosanvallon, 2002; Sen, 2002), zaś ustrój polityczny analizuje się z uwzględnieniem przesłanek ekonomicznych. Ubóstwo ogranicza wolność. Wątpliwe staje się wtedy korzystanie ze zdobyczy demokracji i kształtowanie własnego życia.

\section{Bibliografia}

Bartkowski J., Jasińska-Kania A. (2002), Organizacje dobrowolne a rozwój społeczeństwa obywatelskiego, [w:] A. Jasińska-Kania, M. Marody (red.), Polacy wśród Europejczyków. Wartości społeczeństwa polskiego na tle innych krajów europejskich, Warszawa.

Beetham D., Boyle K. (1994), Demokracja. Pytania i odpowiedzi, tłum. T. Jasudowicz, Torun.

Czerniawska M. (2010), Zmiany wartości i postaw młodzieży w okresie przeobrażeń ustrojowych. Kolektywizm versus indywidualizm. Studium interdyscyplinarne, Białystok.

Czerniawska M. (2011), Za jaką równością i wolnością jesteśmy? - analiza porównawcza postaw studentów diagnozowanych w latach 2003 i 2008, Pedagogika Społeczna, vol. 40.

Czerniawska M. (2013), Postawy w stosunku do aborcji i eutanazji, Pedagogika Społeczna, vol. 50.

Dahl R.A. (1995), Demokracja i jej krytycy, tłum. S. Amsterdamski, Kraków.

Dopuszczalność aborcji $w$ różnych sytuacjach. Komunikat z badań Nr 71/2016, cbos.pl/SPISKOM. POL/2016/K_071_16.PDF, dostęp: 29.07.2019.

Fitoussi J-P., Rosanvallon P. (2002), Czas nowych nierówności, tłum. S. Amsterdamski, Kraków.

Frąckowiak-Sochańska M. (2009), Preferencje ładów normatywnych kobiet wobec wartości w Polsce na przełomie XX i XXI wieku, Poznań.

Gumuła W. (2008), Teoria osobliwości społecznych. Zaskakująca transformacja w Polsce, Warszawa.

Konieczna J. (2002), Wartości polityczne w okresie transformacji w Polsce, na Ukrainie i innych krajach Europy Wschodniej, [w:] A. Jasińska-Kania, M. Marody (red.). Polacy wśród Europejczyków. Wartości społeczeństwa polskiego na tle innych krajów europejskich, Warszawa.

Krzemiński I. (2005), Społeczeństwo obywatelskie i symbole wspólnoty, [w:] M. Drogosz (red.), Jak Polacy przegrywają. Jak Polacy wygrywają, Gdańsk.

KT (2016), Zygmunt Bauman w „El Pais”: mamy do czynienia z kryzysem demokracji, http://wiadomosci.onet.pl/swiat/zygmunt-bauman-w-el-pais-mamy-do-czynienia-z-kryzysem-demokracji/p6vbe4, dostęp: 24.06.2019.

Ludwikowski R.R. (1998), Demokracja, [w:] Encyklopedia socjologii, Warszawa.

Polacy o demokracji. Komunikat z badań Nr 68/2019, cbos.pl/SPISKOM.POL/2019/K_068_19.PDF, dostęp: 24.06.2019.

Radziewicz-Winnicki A. (2008), Pedagogika społeczna w obliczu realiów codzienności, Warszawa.

Reykowski J. (1995), Subiektywne znaczenia pojęcia „demokracja” a ujmowanie rzeczywistości politycznej, [w:] J. Reykowski (red.), Potoczne wyobrażenia o demokracji. Psychologiczne uwarunkowania i konsekwencje, Warszawa. 
Reykowski J. (ed.) (1993), Wartości i postawy Polaków a zmiany systemowe. Szkice z psychologii politycznej, Warszawa.

Sen A. (2002), Nierówności. Dalsze rozważania, przeł. I. Topińska, Kraków.

Wasilewski J. (2005), Ideał demokracji i jego wcielenia, [w:] U. Jakubowska, K. Skarżyńska (red.), Demokracja w Polsce - doświadczenie zmian, Warszawa.

Żardecka-Nowak M. (2001), Czy wspótczesna liberalna demokracja potrzebuje fundamentów filozoficznych? [w:] M. Szulkiewicz (red.), Filozofia i polityka, Kraków. 
